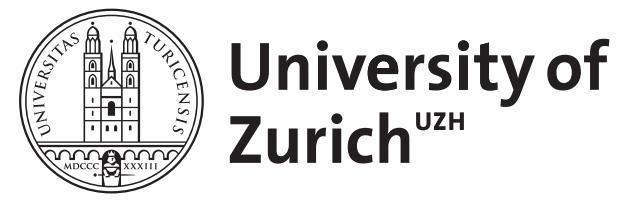

Zurich Open Repository and Archive

University of Zurich

University Library

Strickhofstrasse 39

CH-8057 Zurich

www.zora.uzh.ch

Year: 2014

Towards a modest legal moralism: concept, open questions, and potential extension

Meyer, Frank

DOI: https://doi.org/10.1007/s11572-012-9190-9

Posted at the Zurich Open Repository and Archive, University of Zurich ZORA URL: https://doi.org/10.5167/uzh-101889

Journal Article

Published Version

Originally published at:

Meyer, Frank (2014). Towards a modest legal moralism: concept, open questions, and potential extension.

Criminal Law and Philosophy, (8):237-244.

DOI: https://doi.org/10.1007/s11572-012-9190-9 


\title{
Towards a Modest Legal Moralism: Concept, Open Questions, and Potential Extension
}

\author{
F. Meyer
}

Published online: 20 October 2012

(C) Springer Science+Business Media Dordrecht 2012

\begin{abstract}
The article introduces and critiques Antony Duff's Modest Legal Moralism from a strictly analytical angle. It seeks to illuminate its core tenets and modestly addresses a number of aspects that deserve further elaboration from the author's point of view. Notwithstanding these points of contention the main thrust of the article is the exploration of the constructive potential of Duff's concept. It will be shown that its core elements are well-equipped to come to grips with the lacuna of theorization of supranational criminal justice systems and their criminalization processes.
\end{abstract}

Keywords Modest legal moralism · Criminalization processes · Theories of criminalization · Public wrong - Supranational polity

In this comment I will only briefly lead the reader through the main tenets of Antony Duff's Modest Legal Moralism. Instead of merely summarizing his article, the comment will take a deeper look at what Duff's theory includes and focus on what aspects are in need of further defence. But beyond challenging and defending a modest version of Legal Moralism, which is one of Duff's own goals, I also wish to enunciate some thoughts on its constructive potential. I will explore whether it can be extended to the as yet undertheorised fields of European and International criminal law.

\section{The Concept}

Antony Duff concludes his paper with a disclaimer. He is not intending to offer a new theory of criminalization, but a first step towards a "normative account of the conditions under which, the deliberative procedures through which, the ways in which, the ends for which, a contemporary liberal polity should criminalize conduct" (Duff 2012, 17-18). In

F. Meyer $(\square)$

Chair of Criminal Law and Criminal procedure, University of Zurich, Institute of Law, Zurich, Switzerland

e-mail: frank.meyer@rwi.uzh.ch 
fact, he delineates a pathway to having good reasons for criminal punishment which does not rely on any master principle for criminalization but leaves the decision to structured deliberation and selection processes within each society. However, this approach is less modest than it purports to be. It is grounded in two basic premises. The first one is his specific understanding of the intrinsic (communicative) characteristics of criminal punishment, which he has explained many times before (Duff 2007, 87-88). The second, more implicit one is a concept of ownership of the right to penalize and punish. For him the right to use criminal law as a method of social regulation rests with each respective polity and its representatives; the "us" and "we" in Duff's parlance.

Resting on these pillars Duff's concept starts out from a negative version of Legal Moralism. For a negative Legal Moralist, moral wrongdoing is but a necessary condition to criminalize certain conduct (Duff 2007, 81 et seq.). Positive reasons for eventually resorting to criminal law must be sought elsewhere. Wrongfulness, hence, is only a precondition but not a justification of criminalization. ${ }^{1}$ As a consequence every legal prohibition could theoretically become the object of a criminal prohibition penalizing its violation (Duff 2012, 3, 5). Duff chides traditional negative Legal Moralism for evading the crucial question of what is a good reason to criminalize. The second precept of his concept is supposed to provide the answer. Unlike other moralists Duff differentiates between various types of wrongs and endorses a limited notion of moralism that he has dubbed "modest". To his mind only public wrongs are criminalizable (Duff 2012, 5). This conclusion palpably signifies how his precepts are moulded into practicable criteria. It is inextricably intertwined with his understanding of the function and, if you wish, proprium of criminal punishment. For him criminal punishment is intrinsically unique. ${ }^{2}$ Unlike other regulatory mechanisms, only criminal law sufficiently communicates the moral disapproval of the community and appropriately calls wrongdoers to answer for misdeeds that are of concern for a society as a whole. This premise also implies that criminal law is to specifically focus on instances of moral wrongdoing that constitute public wrongs (Duff 2007, 140 et seq., 51 et seq; Marshall and Duff 1998, 7 et seq.). According to Duff only wrongdoing in this sphere is criminalizable.

But what exactly is a public wrong then? What explains the fundamental difference between the categories of private and public wrongs and who sorts private from public wrongs? Duff's Modest Legal Moralism does not offer us a full-fledged substantive theory of "what to punish". Unlike its big rival, the harm principle, modest Legal Moralism is not a substantive and transcendent theory. As of late, his moralism appears to become more and more process-oriented and positivist. He has stripped his approach of all vestiges of criminalization theories that are generally associated with certain legal systems, for instance, the Rechtsgutstheorie, or certain philosophical schools, be they utilitarian (Mill, Feinberg) or deontological (Kant, Feuerbach). Duff does not intend to impose a certain worldview, but to push us towards a stringent set of questions that we are to ask ourselves to verify that we have good reasons to criminalize. His moralism acknowledges the high volatility of values, ethics, and human preferences. It evades the epistemic impossibility of providing a stable separation of moral from immoral behaviour. The composition and phenomenology of social convictions cannot be deduced from abstract principles. Scholars will continue to face almost

\footnotetext{
${ }^{1}$ For the opposite view see Moore 1997: 33 et seq., 68 et seq.: "all and only moral wrongs should be criminally prohibited"; profound criticisms of this idea can be found in Husak 2008: 196 et seq.; Simester et al. 2010: 649-650; Ashworth 2006: 35.

2 As a consequence instrumentalist cost-effectiveness analysis would be inappropriate and incapable of capturing its proprium; for a similar conclusion see Meyer 2012, 781-785; Seher 2006: 70, 78-79.
} 
insurmountable epistemic obstacles to ascertaining the existence or exact shape of social convictions as long as we do not want to take the mere word or inclination of criminal law theorists, or their hidden substantive theories that might shine through every now and then, for granted. This cannot be the right solution, and it is not the solution Duff has to offer as he has explained before. He is concerned with the structure of the criminal law, not so much its substance. His theory does not rely on an unrevealed substantive meta-theory or allow an omniscient philosopher king to slip in through the back door. In essence, each polity is to figure out for itself which aspects of human life and conduct belong to the public realm and which do not. The members of the polity are to discern what counts as a public wrong (Duff 2007, 143). Duff acknowledges that these choices will be heavily influenced by the basic principles and political ideas on which the polity was founded, but it is another distinctive feature of his approach that he is not trying to derive some commanding principle from constitutional theory or political philosophy. On the contrary, he delegates the selection process to the various criminalization processes in a given polity. Criminalization processes are defined as those through which conduct comes to be or to be treated as criminal (Duff 2012, 7). In this respect Duff is very attentive to the real life of the administration of justice. He identifies several processes of definitional relevance such as prosecutorial and police decision-making or judicial interpretation and application. They all have a bearing on what is being treated as criminal on the streets. In the paper under discussion here, his focus is on legislation as being the most salient criminalization process.

Duff does not equip his legislature with unlimited discretion. Although the polity is the original source and bearer of the right to criminalize and punish, Duff intends to channel their decision-making process into certain structures with a limited number of indispensable (substantive) elements; the so called "Three Gate Filter". These riverbeds of deliberation are best understood as procedural proxy to produce good reasons to criminalize and ensure reflection about certain aspects that eventually will lead to having good reasons. Pursuant to this "Three Gate Filter" only wrongful conduct that warrants a collective response (by the whole community against a public wrong), a response that should make the conduct's wrongfulness salient, ${ }^{3}$ can justify criminal punishment (Duff 2012, 13-14). This test maps, so he submits, the only legitimate route towards criminalization. All legislative proposals have to pass this selection channel. Beyond passing this test no further substantive restriction such as those favoured by advocates of the harm principle need be met. Rather, in what appears to be a synthesis of legal philosophy and political theory, the ultimate selection is left to the society itself as long as it follows the set of questions Duff considers imperative. He does not deny that what is the business of the community and, hence, counts as a public wrong will be heavily influenced by foundational choices of the polity. Accounts of the idea of the public are relative to the defining aims and values of the polity in question. But these choices are acceptable as long as their various manifestations pass the same filter test. This relational character and mutability appears to be a particular strength of Duff's approach.

\section{Open Questions}

This strength of modest Legal Moralism comes at a price. It has serious detrimental sideeffects on the self-proclaimed ambition to provide substantive guidance for legislators and

\footnotetext{
3 This basically means that an adequate public response in the case at hand cannot forgo the intrinsic proprium of punishment even after balancing with other goals and values.
} 
to influence the criminalization process. Whereas all prongs of the "Three Gate test" appear to be highly volatile and relative substantial criteria for the determination of wrongfulness, publicness and salience are lacking as a flipside. Duff is very upfront about the lacunae. He has confessed numerous times that it is structure, much more than substance, that has taken centre stage in his philosophy. As a result, and apart from the two fundamental premises on which the prongs of the "Three Gate test" (at least partly) rest, all public wrongs and crimes are more or less products of self-definition inside the criminalization process. Merely, various (unnamed) other values and goods of the polity that might conflict or outweigh wrongfulness are referred to as substantive limitations. But for the moment they remain unidentified, and their commensurability with supposedly countervailing claims remains an open question.

This analysis gives rise to a number of concerns. Duff trusts too much in processes. He assumes that common people are reasonable, liberal decision-makers who are capable of balancing, and always willing to balance, all aspects at stake and pay tribute to the harmful effects of punishment on potential defendants. To be accurate, he presumes that criminal law-makers are, and think, like the contributors to this symposium. In reality they are not. What is more, the complexity of balancing tests in criminal law is notoriously underestimated (Neumann 2006, 132-123). For instance, Antje Dubois-Pedain's contribution to this symposium shows how difficult and complex a task this is with a view to the balanceof-reasons-test of wrongdoing. But the same goes for the proportionality principle or the ultima ratio principle (Meyer 2012, 781-791). Overall, the "Three Gate test" probably asks too much even of Rousseau-minded actors who strive for the greater public good of the polity. The inherent strength of modest Legal Moralism could turn out to be an inherent deficit here, as long as no sufficiently substantiated and differentiated definitions for the above-mentioned preconditions have been developed. I am not saying that the selfdefinition process is to be considered illegitimate as a consequence. To the contrary, in a pluralistic society democratic self-definition processes seem to be the only feasible solution, ${ }^{4}$ at least for those among us who do not support absolute theories that would strip the sovereign at least in large part of the power of self-determination. But I think that modest Legal Moralism needs a more substantial backbone. Criminal law-makers and theorists inevitably have to discuss substance, especially in the light of the strong majoritarian orientation of theories rooted in Legal Moralism and collective self-determination, let alone their combination. We ought to bear in mind that (de)limiting the scope of the criminal law is very much about the protection of minority rights and spheres of individual liberty against the majority will. We cannot simply rely on majoritarian decision-making processes. Criminal law principles have always been anti-majoritarian and not principles of majoritarian self-empowerment.

Since Duff has called his normative account "Modest Legal Moralism", one is left to wonder whether moralism is not, in effect, the needed substantive adhesive agent. Duff's Modest Legal Moralism does not suffer from the shortcomings of classical conservative versions of Legal Moralism. His Legal Moralism is clearly more creative and formative. And it is modest in the sense that it does not demand that all wrongs must be criminalized. But this renders criminalization a matter of choice constrained only by certain deliberative requirements (Duff 2012, 13, 14). There seem to be no inherent limits in his concept. Rather, his moralism has become more and more positivist. Apart from a few instances of obviously

\footnotetext{
4 The German Constitutional Court has espoused a similar view: see the decisions of the German Bundesverfassungsgericht (BVerfGE) Vol. 123, 267, 408 et seq. For an elaboration of this concept see Meyer 2012, 697 et seq.
} 
pre-legally wrongful behaviour it will simply suffice that a certain conduct has been prohibited by the community (Duff 2007, 92). Deeper ethical implications are not required. One could even ask whether "Modest Legal Moralism" is a misnomer. Bearing this in mind it is a dangerous step to discard constraints that permit us to criminalize only harmful conduct in favour of a broad notion of wrongdoing that encompasses all kinds of conduct that society considers a public wrong (Duff 2012, 16). I am not claiming that we should set out on a new (illusory) search for a set of master principles; but the criminalization question cannot be detached from the question of human rights and civil liberties. For sure, these aspects are waiting on the footstep of the third gate. But they merge into an undefined balancing process. What we would need instead is rock-solid constitutional doctrine. To my mind this is the best antidote to majoritarian overcriminalization as well as to the underestimation of the impact of criminal punishment available at the moment. We have to concede though that even sophisticated constitutional doctrine and strong civil liberties are not a one way street. Both confine a legislature's room to manoeuvre but they also nurture the diametrically opposed concept of "Schutzpflichten" (duties to protect) that could even constitutionally demand criminalization. For instance, the European Court of Human Rights has held many times that human rights not only constrain a legislature's constitutional power to criminalize human behaviour but also, and by contrast, can require the legislative branch to enact new laws that make violations of these human rights a crime. I would therefore suggest that international and national human rights and general legal principles as well as (transnational) judicial review are the cornerstones that we ought to explore, while paying particular attention to the function and impact of criminal punishment.

Finally, we should spend more time on the criminalization processes themselves. As regards the legislative process, we should consider whether the "Three Gate test" is in need of a supplement. For instance, one could think further about the kind of forum in which public wrongs should be determined. Which stakeholders and representatives have to be included in the process? What majorities are needed? Do we need supermajorities before we can convincingly claim that a wrong is a concern for "us", to which "we" as a community have to respond?

More importantly, other processes alongside legislation deserve further exploration. In his article, Duff identifies key processes that complement criminalization on the books through the legislative process. However, his short account is rather an empirical snapshot. What is missing is an effort to weave these processes together and to integrate all of them into the normative account. Conspicuously absent is an answer to the obvious question whether the role these processes currently play is legitimate. Criminal justice systems may differ significantly on a level of principle and constitutional organization when it comes to who participates, on what principled grounds, in the criminalization process. For instance, in the United States criminal justice system, with its much stronger democratic and public justice structure, the definition and prohibition processes are in part deliberately left to prosecutors and courts. The allocation and justification of functions in the administration of criminal justice is quite different in countries that follow the German tradition of the Rechtsstaat, where comparable powers have not been constitutionally conferred on courts and prosecutors-although they are in fact exercised. That said, we should identify the various criminalization processes more thoroughly, based on what their systematic and constitutional functions are and whether they are legally or only sociologically defined processes. They might differ significantly in these respects although they can look quite similar when taken at face value. There is a fundamental categorical difference between what is factually prescribed, seen or treated as criminal and what is normatively to be seen or to be treated as criminal. Duff's theory, however, could provide a 
viable yardstick in distinguishing legitimate from illegitimate processes. But to this end the processes in question need to be rethought as mechanisms for distinguishing private from public wrongs. Such an inquiry would include the crucial question of what processes should exist on the various levels of a criminal justice system to implement the notion of Modest Legal Moralism as well as how and within what limits such a power of selfdetermination should be conferred upon police officers, prosecutors and judges. Until we can find satisfactory answers to the questions raised in this paragraph, it is doubtful whether findings from Duff's inquiry into the legislative process can be extrapolated and brought to fruition for other criminalization processes as well.

Having highlighted this final aspect, it seems clear to me what is missing on the research agenda. Discussing highly relative and volatile criminalization criteria will yield few fruits. What is needed is an orientation not only towards human rights but also and in particular towards processes of self-definition and the criminal law as an instrument of selfgovernance. Despite the above criticism and questions it is normative accounts like Duff's that not only represent significant steps in this direction but also provide illuminating guidance as to how this goal could be pursued. This is the last subject of my comment to which I turn now.

\section{An Extension to Consider}

One of the crucial questions of our time, as we can tell from the controversies surrounding the criminal law-making powers of the EU (Delmas-Marty 1998, 87 et seq.; Kaiafa-Gbandi 2011, 23-26; Meyer 2011, 169 et seq.; Nuotio 2007, 686 et seq.) or the UN Security Council (Fremuth and Griebel 2007, 339; Talmon 2005, 175; De Wet 2005, 183 et seq.), is how such (quasi-) legislative processes outside the setting of a nation state have to be inaugurated, manned, structured and organized in emerging new polities to ensure that the processes themselves and their outcomes can be deemed legitimate. Against the backdrop of a multitude of international organisations enjoying or claiming legislative powers or, at least, a strong normative say, which they often express through soft law, in the area of criminalization, convincing theories as to why and what these organisations could or should be allowed to criminalize are desperately needed. A turn to theories of criminalization is long overdue, to come to grips with the deplorable state of affairs that we witness today. Unfortunately, research activities in this field focus too much on the existence or inexistence of valid criminal law-making powers in international law and treatyinterpretation, and the few frail attempts to start discussing substantive or procedural criminalization theories are overshadowed by the heated debate surrounding the democratic legitimacy of international institutions (Tomuschat 2010, 251-282; Halberstam \& Möllers 2009, 1241-1258). Courts have provided little if any relief. The European Court of Justice sticks to an enforcement-efficacy paradigm, while the German constitutional court has invented the concept of constitutional identity to protect the autonomous law-making powers of a holistic German sovereign against supranational heteronomy. ${ }^{5}$ But, in essence, the court completely sells out to the legislature and turns its back on criminal theory, as we saw in the so called "incest case". ${ }^{6}$ It seems that courts and legislatures content themselves

\footnotetext{
5 Decisions of the German Bundesverfassungsgericht (BVerfGE) Vol. 123, 267, 344.

${ }^{6}$ Decisions of the German Bundesverfassungsgericht (BVerfGE) Vol. 120, 224 et seq. holding that the Rechtsgutstheorie, which is the traditional criminalization theory widely shared among criminal lawyers, finds no basis in the German constitution and, thus, does not constrain the German parliament's power to
} 
with constitutional law and pure policy to resolve disputes surrounding the legality and legitimacy of criminal prohibitions that come before them. Comprehensive criminalization theories with critical normative bite are more or less absent from this current international debate but they remain compelling desiderata. Duff's Modest Legal Moralism might offer considerable guidance in various respects in this discouraging situation. Its basic tenets are much more viable and adjustable in different legal environments, be they national or supranational in kind, than other criminalization theories. Its relational and processoriented character makes Duff's approach particularly suitable for an internationalized, globalized, supranationalized, or transnationalized legal environment. His Modest Legal Moralism is tied neither to a specific national legal system nor to a specific constitutional theory and, thus, is not doomed from the outset in a pluralistic and internationalized setting. Even more important, a determinate account of the civic enterprise that the members of the polity have joined, in his mind, is not a prerequisite for a rational foundation of the criminal law. I infer from this not only a strong conceptual flexibility as to who could forge a civic polity and what their aims and values might be, but also the possibility of using criminal law in the evolution process of new transnational or multilevel polities. Such a position contrasts starkly with those views that take the pre-existence of a sufficiently homogeneous demos or a state-like constitutional structure to be indispensable for legitimate criminal law-making. I would therefore submit that the path Duff charts in this paper and prior works marks a potent starting point for reflections on international or supranational criminalization. But I suspect that he would require at least two things. First, a criminal law polity has to exhibit some sort of robust moral fabric and an idea of their res publica; otherwise criminal punishment would in his eyes be pointless. Without this epistemic social condition it could neither express moral censure nor punish public moral wrongs (since there would simply be no public realm). Second, such a polity has to have installed procedural mechanisms to process acts of wrongdoing and ultimately to hold wrongdoers accountable. None of the international institutions of multilevel governance we know, apart from international tribunals such as the ICC or the ICTY, would pass such a two-prong test. In particular, the EU is not yet protecting the moral fabric of its citizenry; its technical, functionalistic outfit appears to be rather remote from the social mores that govern the lives of regular EU citizens. Conversely, we have to call into question the way in which national courts punish breaches of EU law on behalf of the Union, although the EU is not a moral polity. But I am not sure whether Duff's moralism is not formative and creative enough to come to terms with these impediments. At the very least, the transposition of Duff's reasoning into an international environment urges us to think more carefully about the necessary (perhaps social and pre-legal) preconditions and configuration of polities that legitimately avail themselves of the power to enact criminal laws. We have to ask ourselves to whom a wrongdoer could be answerable in a system of international multilevel criminal governance.

\section{References}

Ashworth, A. (2006). Principles of criminal law (5th ed.). Oxford: Oxford University Press. Delmas-Marty, M. (1998). The European Union and penal law. European Law Journal, 4, 87-115.

Footnote 6 continued enact criminal prohibitions. In the court's view criminal legislation is primarily a crucial choice of democratic self-determination of a people executed by its elected representatives. 
De Wet, E. (2005). The Security Council as a law maker: The adoption of (Quasi)-judicial decisions. In R. Wolfrum \& V. Röben (Eds.), Developments of International Law in Treaty Making (pp. 183-225). Berlin: Springer.

Duff, R. A. (2012). Towards a modest legal moralism. Criminal Law and Philosophy.

Duff, R. A. (2007). Answering for crime. Oxford/Portland, Oregon: Hart.

Halberstam, D., \& Möllers, C. (2009). The German Constitutional Court says "Ja zu Deutschland!". German Law Journal, 10, 1241-1258.

Fremuth, M., \& Griebel, J. (2007). On the Security Council as a Legislator: A Blessing or a Curse for the International Community? Nordic Journal of International Law, 76, 339-361.

Husak, D. (2008). Overcriminalization. Oxford/New York: Oxford University Press.

Kaiafa-Gbandi, M. (2011). The Importance of Core Principles of Substantive Criminal Law for a European Criminal Policy respecting Fundamental Rights and the Rule of Law (pp. 7-34). Criminal Law Review: European.

Marshall, S. E., \& Duff, R. A. (1998). Criminalization and Sharing Wrongs. Canadian Journal of Law and Jurisprudence, 11, 7-22.

Meyer, F. (2012). Strafrechtsgenese in internationalen Organisationen (on the genesis of criminal law in international organisations). Baden-Baden: Nomos.

Meyer, F. (2011). Das Strafrecht im Raum der Freiheit, der Sicherheit und des Rechts. Europarecht, 46, 169-195.

Moore, M. (1997). Placing Blame. Oxford: Clarendon Press.

Neumann, U. (2006). Das Verhältnismäßigkeitsprinzip als strafbegrenzendes Prinzip. In A. von Hirsch, K. Seelmann, \& W. Wohlers (Eds.), Mediating Principles (pp. 128-137). Baden-Baden: Nomos.

Nuotio, K. (2007). Criminal Law of a transnational polity. In H. Müller-Dietz (Ed.), Festschrift für Heike Jung (pp. 685-698). Baden-Baden: Nomos.

Seher, G. (2006). Kann Strafrecht "subsidiär sein? Aporie eines "unbestrittenen" Rechtsgrundsatzes. In A. von Hirsch, K. Seelmann, \& W. Wohlers (Eds.), Mediating Principles (pp. 70-82). Baden-Baden: Nomos.

Simester, A. P., Spencer, J. R., Sullivan, G. R., \& Virgo, G. J. (2010). Simester and sullivan's criminal law (4th ed.). Oxford/Portland, Oregon: Hart.

Talmon, S. (2005). The Security Council as world legislature. American Journal of International Law, 99 , $175-193$.

Tomuschat, C. (2010). Lisbon-Terminal of the European Integration Process? The Judgment of the German Constitutional Court of 30 June 2009. ZaöRV, 70, 251-282. 